NÃO APENAS, MAS EM VEZ DISSO $O$ carvalho e o pinheiro: Freud e o estilo romântico. Ines Loureiro.

São Paulo: Escuta: Fapesp, 2002. 376 p.

\section{Regina Herzog}

Psicanalista; professora do Programa de Pósgraduação em Teoria Psicanalítica da UFRJ

O livro - fruto de um trabalho acadêmico - nos coloca, de saída, uma indagação: qual a pertinência, nestes tempos pós-modernos, de um debate sobre a relação entre o Romantismo e a Psicanálise quando ambos parecem remeter a problemáticas consideradas superadas? Em outros termos, haveria ainda lugar para essa discussão quando não temos mais a esperança romântica de alcançar a totalidade e quando a instância simbólica que sustenta o desejo vem sendo questionada por todos os lados?

Entretanto, a discussão se torna atual pelo modo singular como Ines Loureiro escolhe encaminhar a questão: em lugar de descrever ou explicar o que seja o Romantismo, propõe-se a pensar o "estilo romântico”, enfatizando nele não um anseio pela totalidade, mas principalmente o seu vigor revolucionário. Quanto à psicanálise, a autora não a reduz a um sistema de idéias ou a um saber datado, mas a torna viva através do movimento de criação de Freud frente à sua época. Dessa maneira é trazida para o centro da discussão uma imagem de homem em processo de esfacelamento e que, nos dias de hoje, se configura como um tema privilegiado pela própria psicanálise.

Postulando uma não-identidade entre Romantismo e Psicanálise, e tendo como programa de trabalho "o cotejamento da obra freudiana com as aspirações próprias ao estilo romântico", Ines trabalha os temas fundamentais da psicanálise, temas que nos perturbam; dentre eles, a questão do monismo, da filosofia da Natureza, da especulação, do racionalismo versus irracionalismo.

Para desenvolver esta argumentação, o livro é dividido em três partes. A primeira consiste no levantamento da vasta bibliografia existente acerca das relações entre Freud e o Romantismo. Tarefa de fôlego não só devido à amplitude de textos sobre o assunto, como também pela diversidade de perspectivas encontrada entre os comentadores. Conforme assinala em sua exposição, a ausência de uma noção explícita e bem delimitada de Romantismo dificulta estabelecer diferenças e aproximações entre os dois domínios.

Essa dificuldade, no entanto, não se constitui em obstáculo na construção de sua hipótese central, a saber: a de que Freud não é nem um romântico nem um homem das Luzes, mas um pensador híbrido. Ao mesmo tempo, considera imprescindível circunscrever uma noção de Romantismo que lhe permita operar junto ao pensamento freudiano. 
Garimpando nessa literatura os elementos necessários para construir uma noção "clara, ampla e operacionalizável" com a qual possa trabalhar, a autora delimita a noção de "estilo romântico", empreendimento ao qual se dedica na segunda parte do livro. Ao escolher os autores que possibilitam a "própria (des)montagem do universo romântico”, seu procedimento confere consistência à argumentação. Sem descartar as múltiplas e diversas formulações sobre o Romantismo, Ines recorre à lógica do 'não apenas, mas em vez disso' para positivar as divergências e chegar à noção de 'estilo romântico' através da qual vai estabelecer um diálogo com a teoria freudiana. Essa lógica consiste em trabalhar com as várias figuras do Romantismo, "que se somam e se sucedem, sem se anular, mesmo sendo incompatíveis entre si". O que desemboca na afirmação do Romantismo "como um estilo de experienciação de si e do mundo".

Essas duas partes, ainda que preparatórias para a questão maior do livro, merecem nossa atenção. Trata-se de uma pesquisa cujo valor é inestimável, sobretudo porque, recusando-se a fazer uma exegese nos moldes tradicionais, estabelece um confronto com as diversas perspectivas, posicionando-se criticamente a todo o momento. Este diálogo com os vários comentadores do Romantismo ganha um colorido no modo como é empreendido: com um tom irônico quem sabe bem no estilo romântico Ines cria uma atmosfera leve que em muito facilita nossa leitura.

A terceira parte focaliza a questão tecida ao longo do texto - Freud e o estilo romântico. Para poder confrontar Romantismo e teoria freudiana, uma primeira estratégia é colocada em prática: em lugar de optar por apresentar concei- tos da Psicanálise afins aos do Romantismo, prefere partir de 'temas-chave' da obra freudiana, dando relevo às posições de Freud, às suas 'convicções filosóficas', idéia que toma emprestado de Jankélévitch. Tal opção de, além da obra, inserir o homem, não é nada simples posto que, com essa estratégia, sempre se corre o risco de confundir um e outro, quando não se acaba caindo na armadilha de uma interpretação psicanalítica dos motivos que levam o homem a produzir uma obra. Ines, no entanto, não se perde neste campo e cumpre a tarefa com maestria, o que certamente se deve ao seu rigor metodológico.

Abordando, nos capítulos que compõem esta última parte, "a escrita, a concepção de ciência e a crítica dos valores” em Freud, o livro alcança seu objetivo maior: o de conferir a Freud a condição paradoxal de 'iluminista sombrio', acompanhando Yovel; porém, vai além deste comentador ao mostrar como Freud herda e converte noções capitais do Romantismo, fazendo a psicanálise derivar para uma "ética da finitude, ou ainda, da renúncia às ilusões”. Hoje, num mundo esfacelado, onde valores e ideais parecem ter perdido qualquer razão de ser, essa derivação ganha consistência. Parafraseando a autora, este legado faz de Freud 'não apenas' um homem do seu tempo, mas 'apesar disso' um homem lançado no futuro.

A originalidade do trabalho reside, justamente, no modo singular de pensar a relação entre Romantismo e Psicanálise. Através dela a autora nos apresenta a possibilidade de romper o limite que o mundo nos impõe, abrindo uma trilha diferenciada do paradoxo romântico, qual seja: "o desejo de unidade e totalidade" e "a consciência de que este anseio é impossível”. Uma trilha que esca- 
pa, melhor ainda, que implode o binômio otimismo/pessimismo e que, de modo irônico, aposta na criação de múltiplos prazeres — “episódicos, limitados e fugazes”, como diz Ines, "mas nem por isso menos valiosos".

Recebido em 28/4/2003.

Aprovado em 19/5/2003.

Regina Herzog

rherzog@marlin.com.br

O CORPO DA EXPERIÊNCIA

Corpo e escrita: Relações entre memória e transmissão da

experiência. Ana Costa. Rio de Janeiro: Relume-Dumará, 2001, 168 p.

\section{Maria Cristina Poli}

Psicanalista, membro da Appoa, professora da Faculdade de Psicologia da PUC/RS, doutoranda da Universidade de Paris 13.

Quem não conhece a famosa imagem de Proust que, ao molhar madalenas no chá tem, subitamente, sua infância evocada e vivenciada, como uma experiência conjugada no presente? Pois aproveitemos a analogia: Ana Costa, em Corpo e escrita, nos oferece a oportunidade de revisitar os fundamentos da psicanálise, notadamente a teoria das pulsões e o registro da memória. O gosto que provamos em sua leitura nos indica os matizes ainda inexplorados de um antigo e árduo terreno que constitui - por assim dizer - a "infância” da psicanálise: a metapsicologia freudiana.

São justamente os impasses das conceituações de Freud, e também de Lacan, que a autora vai explorar e reinscrever.
Seu ponto de partida é aquele, único, a partir do qual um psicanalista se autoriza: a sua própria experiência. A autora nos presenteia, assim, com uma obra que testemunha seus mais de 20 anos de trabalho clínico e sua experiência como responsável pela condução de uma instituição de formação em psicanálise.

Neste seu segundo livro, Ana Costa, dá continuidade às questões trabalhadas em $A$ ficção de si mesmo: Interpretação e ato em psicanálise, acerca das condições de representação do sujeito. Tanto Freud como Lacan propuseram em suas obras o trabalho com o inconsciente como uma espécie de "semiótica". Significantes e traços mnêmicos são representantes que constituem marca, registrando e apagando, pelo mesmo movimento, o traumático desvelamento do real. Sexo e morte, os representantes pulsionais deste real, fazem borda ao corpo; é neste encontro do corpo com seu registro, com sua escrita, que Ana Costa inscreve seu trabalho.

Que esta escrita tenha um endereço pode ser pensado como interpretante do axioma lacaniano "o inconsciente é o social”. Em uma leitura inovadora, corpo e memória são trabalhados por Ana Costa como fenômenos transicionais que dialetizam a interface coisa, nome e endereço. É na fronteira eu-Outro, e suas mediações, que somos convidados a repensar a experiência do inconsciente como constituindo um campo relacional. Impõe-se, então, a questão: o que dessa experiência se transmite, no além daqueles a quem é dado compartilhá-la de forma imediata? Isto é, como é que a experiência pode fazer memória na cultura?

A tese aqui sustentada é de que as condições de construção de um registro e sua transmissão relevam uma particular inscrição do sujeito no campo do Outro, quando o mais singular ganha valor de 